口腔に発生した孤立性線維性腫瘍の 1 例

\author{
岡 部孝一・宮田＼cjkstart勝・高木純一郎 \\ 鈴木 円·坂下英明 $*$ ·草間 薰 $* *$
}

\title{
A case of a solitary fibrous tumor of the oral cavity
}

\author{
Koichi Okabe $\cdot$ Masaru Miyata $\cdot$ Junichiro Takagi \\ Tsubura Suzuki $\cdot$ Hideaki Sakashita ${ }^{*} \cdot$ Kaoru Kusama ${ }^{* *}$
}

\begin{abstract}
We report a solitary fibrous tumor arising in the oral cavity.
A 27-year-old woman had been aware of a tumor in the right side of the mandible since January 1998. The tumor was found by her dentist on dental therapy, and she was referred to our department on March 19, 1999. On palpation a spherical tumor $1.5 \mathrm{~cm}$ in diameter was found in the gingivobuccal fold of the right mandibular premolar. It was a painless movable tumor and there was no adhesion to the skin or perceptional anomaly. The teeth adjacent to the tumor had no anomaly. Echography and computed tomography showed a clearly demarcated tumor.

The tumor was enucleated under local anesthesia on April 7, 1999. Histopathologically and immunohistochemically, it was diagnosed as a solitary fibrous tumor. The patient, who has been followed up on an outpatient basis, has had no recurrence and is making good progress.
\end{abstract}

Key words: solitary fibrous tumor (孤立性線維性腫瘍), oral（口腔）, CD34 (CD34), immunohistochemical study（免疫組織化学的検討）

\section{緒 \\ 言}

今回われわれは, 煩粘膜に発生した孤立性線維性腫瘍 (Solitary fibrous tumor, 以下 SFT と略す) の 1 例を経験 したので, その概要を報告する。

\section{症例}

患 者 : 27歳, 女性.

初 診: 1999年 3 月

石川県立中央病院歯科口腔外科

(主任 : 宮田 勝医長)

*明海大学歯学部口腔外科学教室第二講座

(主任 : 坂下英明教授)

**明海大学歯学部口腔病理学教室

(主任 : 草間 薰教授)

Department of Dentistry and Oral Surgery, Ishikawa Prefectural Central Hospital (Chief: Masaru Miyata)

${ }^{*}$ Second Department of Oral and Maxillofacial Surgery, Meikai University School of Dentistry (Chief: Prof. Hideaki Sakashita)

**Department of Oral Pathology, Meikai University School of Dentistry (Chief: Prof. Kaoru Kusama) 受付日：平成12年11月27日
主 訴 : 右側煩粘膜下腫瘤.

既往歴 : 扁桃周囲炎, アレルギー性鼻炎の既往があるが 経過は良好である。

家族歴：特記事項なし.

現病歴：1998年 1 月頃より右側煩粘膜下腫瘤に気づいて いたが, 特に疼痛なく放置していた。歯科治療時に同腫瘤 を指摘され，紹介にて当科を受診した．

現 症:

全身所見：体格中等度, 栄養状態良好.

口腔外所見：顔貌は左右対称で異常を認めなかったが, 右側下顎小臼歯相当部皮下に直径 $1.5 \mathrm{~cm}$ 程度の腫瘤を触知 した. 皮虐との癒着, 知覚異常を認めず, 炎症所見も欠いて いた. 所属リンパ節は触知しなかった。

口腔内所見 : 右側下顎小臼歯部の歯肉煩移行部粘膜下に 直径約 $1.5 \mathrm{~cm}$, 無痛性, 可動性, ほほ球形の腫瘤を触知した (写真 1 ). 近接する歯および被覆粘膜に異常を認めなかっ た。

エコー所見 : 右側下顎部皮下に単房性, 扁平形, 境界明 瞭な腫瘤像が認められた. 


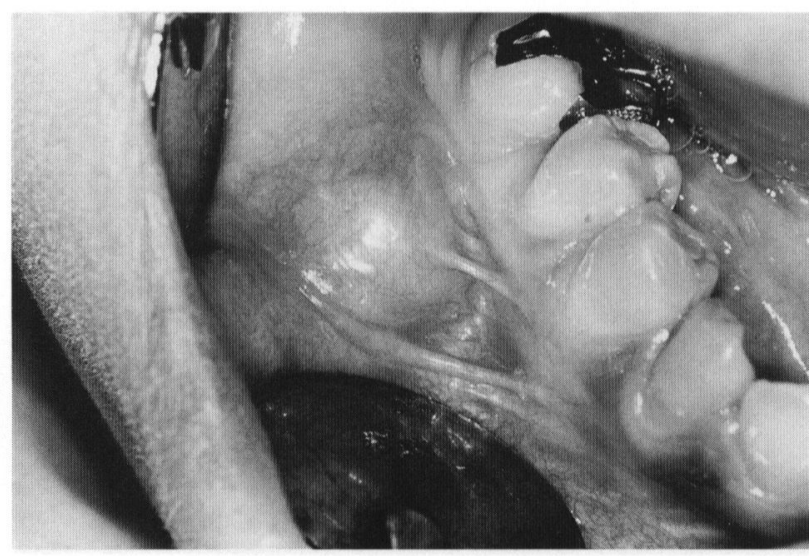

写真 1 初診時口腔内写真

右側下顎小臼歯部の歯肉煩移行部に直径約 $1.5 \mathrm{~cm}$, 無 痛性, 可動性, ほほ球形の腫瘤を触知した。

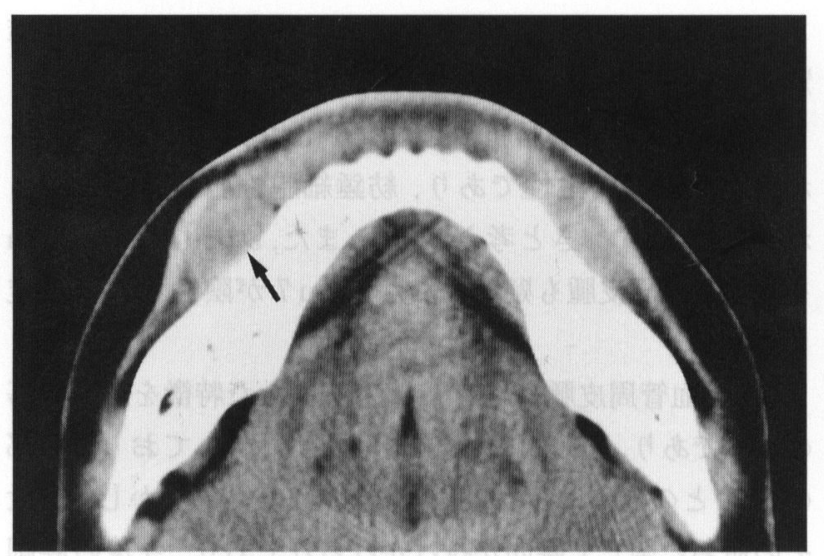

写真 2 CT 写真

右側頪部皮下に直径 $15 \times 9 \mathrm{~mm}$ の境界明瞭な腫瘤とし て認められた。

CT 所見 : 右側下顎部皮下に境界明瞭で, 内部均一な 15 $\times 9 \mathrm{~mm}$ の腫瘤像が認められた（写真 2 ).

臨床診断：右側下顎小臼歯部良性腫瘍

処置および経過 : 同年 4 月】, 局所麻酔下にて腫瘍摘 出術を施行した. 粘膜切開にて腫瘍を露出させると, 腫瘤 は薄い線維性の被膜に覆われ, 境界は明暸であった. 被膜 上で鈍的に剥離して, 腫瘍を摘出した。一部で周囲筋肉と の剥離が困難であった. 骨, 神経などの周囲組織との癒着 は認められなかった. 現在, 外来通院にて経過を観察中で あるが, 再発の徴候もなく, 経過は良好である.

摘出物所見: 腫瘍は $15 \times 12 \times 11 \mathrm{~mm}$ 大, 弾性硬, 充実性 で (写真 3 ), 割面は灰白色で, 壊死, 出血は認められな

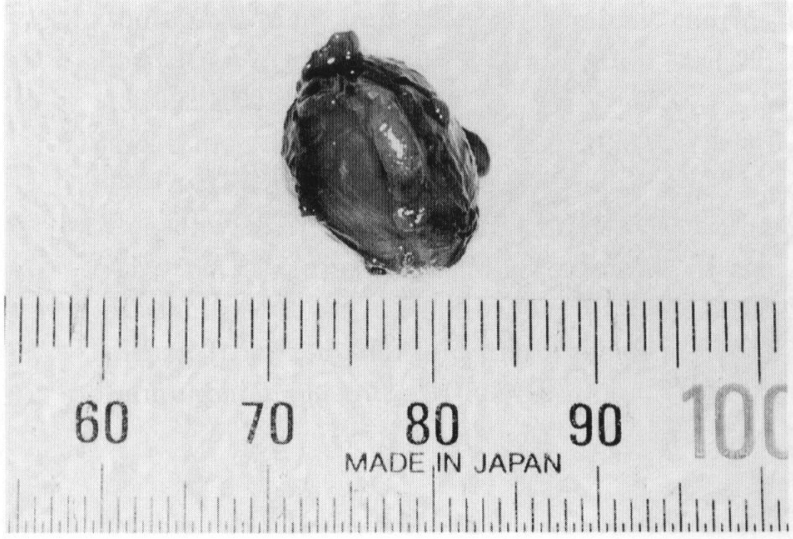

写真 3 摘出物写真

腫瘤は薄い線維性の被膜に覆われ，境界は明瞭であっ たが, 一部で周囲筋肉との剥離が困難であった.

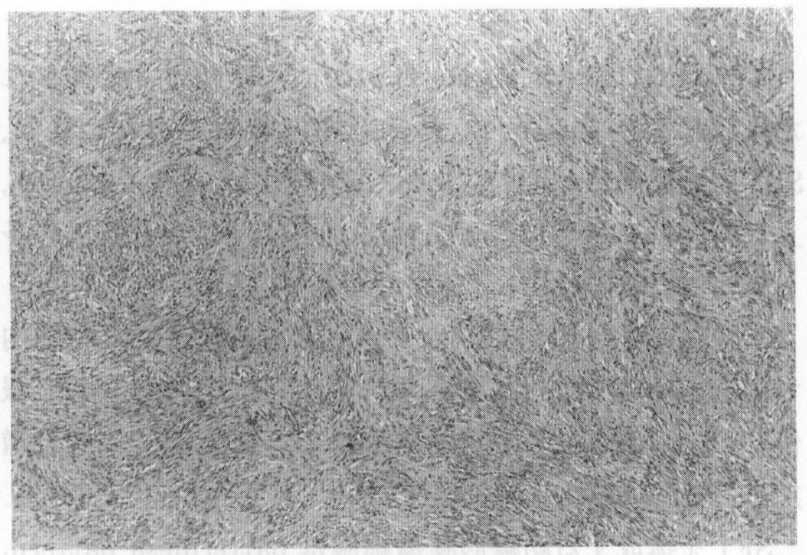

写真 4 病理組織像 (HE 染色, 弱拡大) 組織学的には境界明瞭な病変で, 多角形ないし紡錘形 の細胞がびまん性ないし束状に増生し，部位により storiform pattern が認められた.

かった.

病理組織学的所見 : 腫瘍組織は, 境界明瞭な病変で, 多 角形ないし紡錘形の細胞がびまん性ないし束状に増生し, 部位により storiform pattern が認められた（写真 4 ). 細 胞は比較的よく揃っており, 高度な細胞異型はないものの, 部位により細胞密度は高く, 核分裂像も少なからず認めら れた (写真 5 ). 浸潤性増殖, 壊死は認められなかった.

免疫組織化学的所見 : CD34,ビメンチンが陽性 (写真 6 ), EMA, ケラチン, S-100は陰性, アクチンが一部陽性であっ た。

病理組織診断 : SFT. 


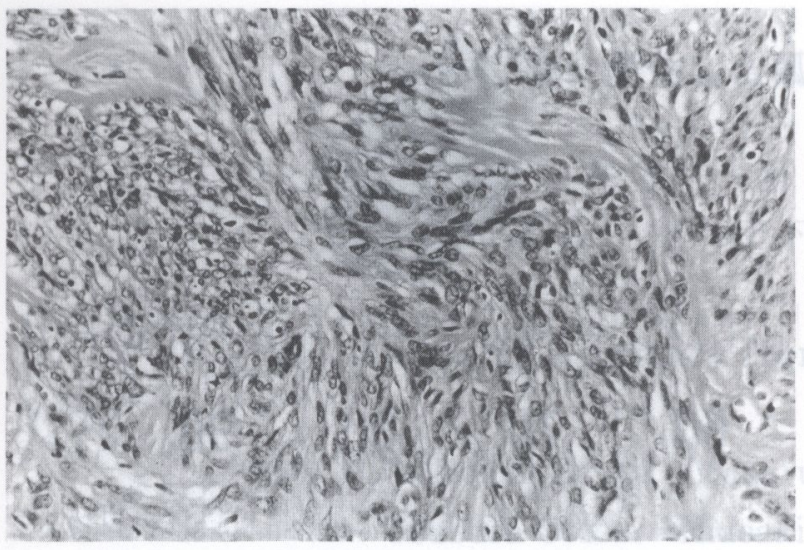

写真 5 病理組織像 (HE 染色, 強拡大) 細胞は比較的よく揃っており, 高度な細胞異型はない ものの, 部位により細胞密度は高く, 核分裂像も少なか らず認められた。

\section{考}

察

SFT は1931年 Klemperer ら 1)によって初めて報告され た胸膜に発生するまれな紡錘形細胞腫瘍である。近年， SFT の疾患概念がさまざまな領域で知られるようになり， 上気道, 眼窩, 唾液腺等の頭頸部, 腹腔などの胸腔以外の多 くの部位で報告されるようになった2）.

口腔内に発生した症例は, われわれが涉猟しえた範囲内 では, Gunhan ${ }^{3)}$ による舌下腺に発生した症例が最初の報 告で, 以後, 煩部・類粘膜を中心にここ数年特に報告が増 加してきている4～6).

SFT を構成する紡錘形腫瘍細胞は patternless pattern, hemangiopericytoma-like pattern, storiform pattern な どの多様な組織パターンを示すことが多く, 組織学的には 多様である。したがって, SFTが胸膜外で発生した場合に は, 本腫瘍の診断は困難を伴う場合が多い 7).

CD34は骨䯣の造血幹細胞に存在する細胞膜貫通型の糖 蛋白で, 線維芽細胞関連抗原であるが, Renshaw 5 8) が 1994年, SFT との関連性を報告して以来，その発現がきわ めて高率に認められるとの報告が相次ぎ, SFT の報告が飛 躍的に増加してきている.

本症例のように口腔内に発生した場合には, 鑑別すべき 疾患は多い. 悪性腫瘍では線維肉腫, 悪性神経鞘腫, 悪性線 維性組織球腫, 悪性血管周皮腫, 良性では神経原腫瘍, 神経 鞘腫, 血管平滑筋腫, 神経線維腫, 血管周皮腫, 神経周膜腫, 紡錘細胞性脂肪腫, 孤立性筋線維腫, デスモイド腫瘍との 鑑別が必要になる ${ }^{4 \sim 6)}$.

そのうち, CD 34が発現するものは, 神経線維腫, 良性神 経鞘腫瘍, 神経鞘腫, 神経腫, (血管) 平滑筋腫, 血管周皮腫 である ${ }^{6)}$ ，それゆえ，診断に当たっては，本症例のごとく，

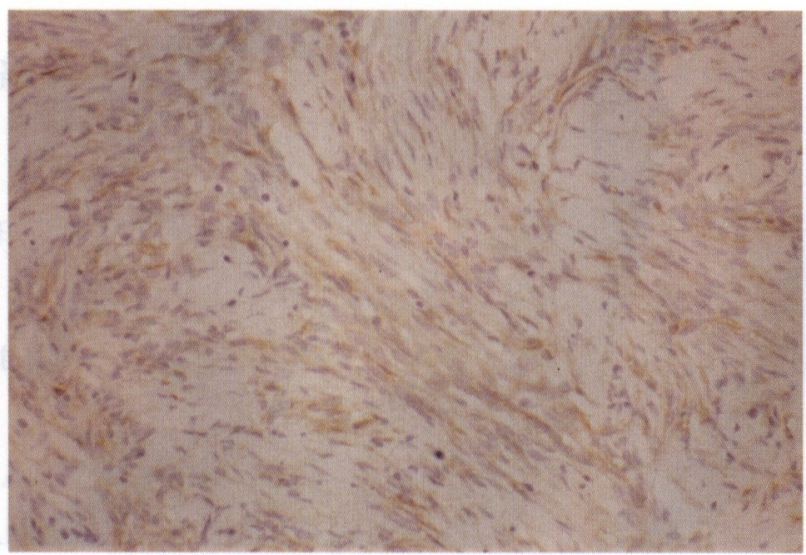

写真 6 免疫組織化学染色像 CD34に陽性を示した.

さらに S-100などの他の免疫染色との組み合わせにより鑑 別診断を行うのが一般的である 4 ～6).

本症例では, 一部脂肪細胞への分化ともとれる像がみら れたが，S-100が陰性であり，紡錘細胞性脂肪腫が否定さ れ, 変性像とすべきと考えられた.また, storiform pattern をとる神経周皮腫も疑われたが, Leu 7 が院性なので否定 された。

なお，血管周皮腫はSFT と最も類似した特徴を示す腫瘍 の 1 つであり, 免度組織化学的所見も類似しており，一部 の SFT との鑑別はきわめて困難である ${ }^{2,4)}$. しかし，最近 その命名に関して疑問が投げかけられており，今後の詳細 な検討が待たれる2).

口腔内に発生したSFT の予後に関しては, 長期間経過を 観察した報告が少ないものの，おおむね良好である ${ }^{5)}$ ．し かし, 細胞異型, 高い細胞密度, 核分裂像の増加, 腫瘍壊死 のうち少なくとも 1 つの組織学的異型が認められた症例で 再発, 転移が認められたり，良性の細胞形態にもかかわら ず，再発を認めたとの報告もある ${ }^{2}$ ). 本症例は術後 1 年 5 か月が経過し, 再発傾向は認められないが,引き続き厳重 な経過観察が必要である。

本論文の要旨は, 第 54 回日本口腔科学会総会 $(2000$ 年 5 月 12 日, 東京)において発表した。

\section{引用 文 献}

1) Klemperer, P. and Rabin, C.B.: Primary neoplasm of the pleura: a report of five cases. Arch Pathol 11: 385-412 1931.

2）長谷川匡：孤立性線維性腫瘍および類似病変。病理 と臨床 18: 117-122 2000. 
3) Gunhan, O., Yildiz, F.R., et al.: Solitary fibrous tumour arising from sublingual gland: report a case. J Laryngol Otol 108: 998-1000 1994.

4) Perez-Ordonez, B., Koutlas, I.G., et al.: Solitary fibrous tumor of the oral cavity: an uncommon location for a ubiquitous neoplasm. Oral Surg 87: 589-593 1999.

5）白水敬昌, 堀田文雄, 他 : 煩部に発生した Solitary fibrous tumor の 1 例. 口科誌 48: 339-343 1999.

6) Lukinmaa, P.L., Hietanen, J., et al.: Solitary fibrous tumour of the oral cavity: clinicopa- thological and immunohistochemical characterization of three cases. J Oral Pathol Med 29: 186-192 2000.

7）横井豊治, 太田裕元, 他 : 胸膜の孤立性線維性腫湯. 病理と臨床 14: 1361-1368 1996.

8) Renshaw, A.A., Pinkus, G.S., et al.: CD34 and $\mathrm{AE} 1 / \mathrm{AE} 3$ : diagnositic discriminants in the distinction of solitary fibrous tumor of the pleura from sarcomatoid mesothelioma. Appl Immunohistochem 2 : 94-102 1994. 